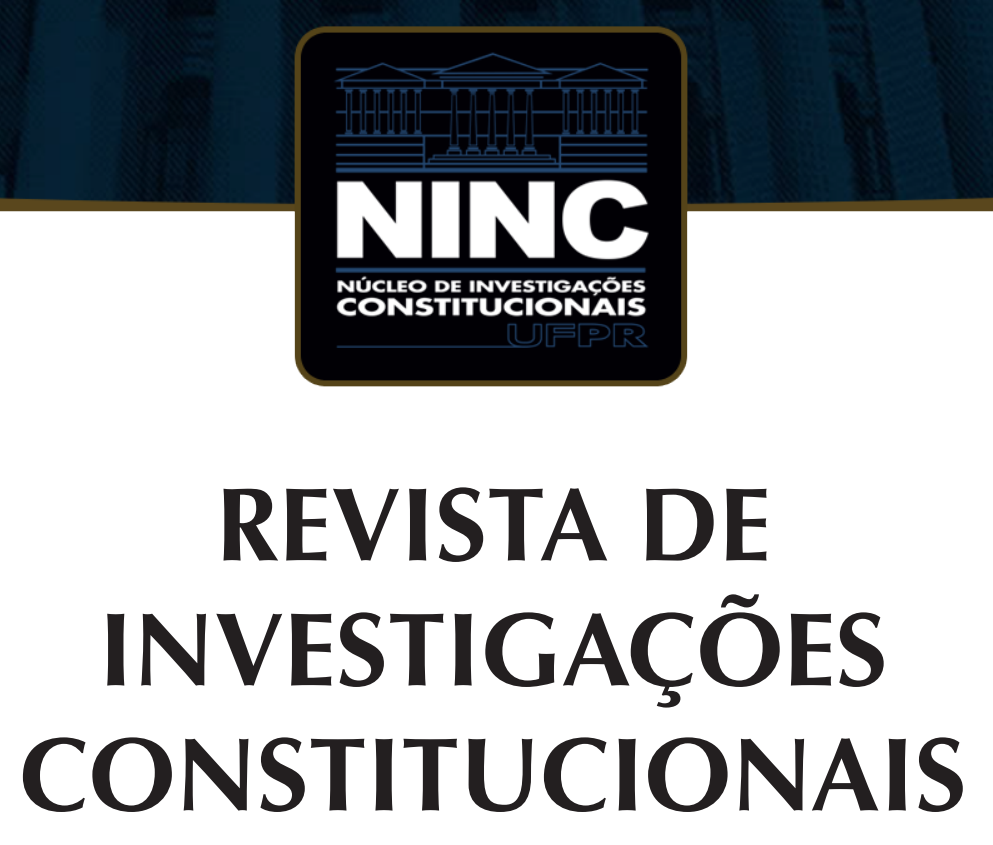

JOURNAL OF CONSTITUTIONAL RESEARCH

vol. 8 | n. 2 | maio/agosto 2021 | ISSN 2359-5639 | Periodicidade quadrimestral Curitiba | Núcleo de Investigações Constitucionais da UFPR | www.ninc.com.br 


\title{
A constitucionalidade do DNA na persecução penal: o direito à autodeterminação informativa e o critério de proporcionalidade no Brasil e na Alemanha
}

\section{The constitutionality of DNA in criminal prosecution: the right to informative self-determination and the proportionality criterion in Brazil and Germany}

\author{
ANITA SPIES DA CUNHA I,* \\ ' Universidade Federal do Rio Grande do Sul (Porto Alegre, Rio Grande do Sul, Brasil) \\ anitadacunha@hotmail.com \\ https://orcid.org/0000-0002-2702-6425
}

TAYSA SCHIOCCHET II, **

"Universidade Federal do Paraná (Curitiba, Paraná, Brasil) taysa_sc@hotmail.com https://orcid.org/0000-0002-6703-9036 Recebido/Received: 09.06.2020 / June $9^{\text {th }}, 2020$ Aprovado/Approved: 02.07.2021 / July 2 ${ }^{\text {nd }}, 2021$

\section{Resumo}

No Brasil, a discussão sobre a constitucionalidade dos bancos de perfis genéticos, no Recurso Extraordinário n 973.837/MG, tem se concentrado no direito penal e processual penal (especialmente no direito de não autoincriminação), até o momento. Em outros países, a implementação dessa tecnologia considerou também a proteção da privacidade e dos dados genéticos. Na Alemanha,

\section{Abstract}

In Brazil, the discussion about the constitutionality of DNA databases, in the Recurso Extraordinário no 973.837/MG, focuses mostly on criminal law and criminal procedure law (specially on the right to avoid self-incrimination), until now. In other countries, the implementation of this technology also considered the protection of privacy and of genetic data. In Germany, the right to informational

\footnotetext{
Como citar esse artigo/How to cite this article: CUNHA, Anita Spies da; SCHIOCCHET, Taysa. A constitucionalidade do DNA na persecução penal: o direito à autodeterminação informativa e o critério de proporcionalidade no Brasil e na Alemanha. Revista de Investigações Constitucionais, Curitiba, vol. 8, n. 2, p. 529-554, maio/ago. 2021. DOI: 10.5380/rinc.v8i2.74420

"Mestranda em Direito na Universidade Federal do Rio Grande do Sul (Porto Alegre-RS, Brasil), na ênfase "Direito Europeu e Alemão" do Centro de Estudos Alemães e Europeus da UFRGS-PUCRS. Graduada em Direito pela UNISINOS/RS. Advogada. Realizou intercâmbio na Carl von Ossietzky Universität Oldenburg/Alemanha (2015/1), cursando Comparative and European Law na Hanse Law School. Integrante da Clínica de Direitos Humanos da UFPR. E-mail: anitadacunha@hotmail.com.

* Professora Adjunta de Teoria do Direito e Direitos Humanos da Faculdade de Direito e PPGD da Universidade Federal do Paraná (Curitiba-PR, Brasil). Doutorado em Direito (UFPR), com período de estudos doutorais na Université Paris I - Panthéon Sorbonne e na Facultad Latinoamericana de Ciencias Sociales - FLACSO (Buenos Aires). Pós-doutorado pela Universidad Autónoma de Madrid (UAM), na Espanha. Professora visitante da Université Paris X. Advogada. Coordenadora da Clínica de Direitos Humanos da UFPR (CDH|UFPR). E-mail: taysa_sc@hotmail.com.
} 
o direito à autodeterminação informativa serve como parâmetro de constitucionalidade ao armazenamento de perfis genéticos. Diante disso, este artigo objetiva identificar e analisar os critérios de proporcionalidade utilizados pelo Tribunal Constitucional Alemão frente ao uso de perfis genéticos para fins de persecução criminal e ao direito à autodeterminação informativa e, por consequência, suas possíveis implicações à análise de constitucionalidade no Brasil. A metodologia abarca pesquisa qualitativa, de cunho exploratório, com estudo de caso comparado entre o Brasil e Alemanha e fontes bibliográficas e documentais. Conclui-se que os bancos de perfis genéticos atingem o direito à autodeterminação informativa e, por isso, a decisão judicial que impõe a coleta de DNA deverá ponderar o interesse público e o privado considerando elementos do caso concreto (prognóstico negativo). A ausência dessa análise implicará em uma restrição injustificada do direito à autodeterminação informativa e, consequentemente, na desproporcionalidade e inconstitucionalidade da medida..

Palavras-chave: Bancos de perfis genéticos; Autodeterminação informativa; Bundesverfassungsgericht; Proporcionalidade; Direitos fundamentais. self-determination is the constitutionality parameter to the storage of genetic profiles. Thus, this article aims to identify and analyze the criteria of proportionality used by the German Constitutional Court facing the use of genetic profiles in criminal prosecution and the right to informational self-determination and, as consequence, its implications to the Brazilian constitutionality analysis. The methodology adopted is qualitative exploratory research with compared case study between Brazil and Germany and bibliographic and documental sources. We conclude that DNA databases affect the right to informational self-determination and therefore the judicial decision that imposes DNA collection must ponder the public and private interest, considering elements of the particular case (negative prognostics). The absence of this analysis implicates in an unjustified restriction to the right of informational self-determination and consequently in the disproportionality and unconstitutionality of the measure.

Keywords: DNA Databases; Informational self-determination; Bundesverfassungsgericht; Proportionality; Fundamental rights.

\section{SUMÁRIO}

1. Introdução; 2. O direito à autodeterminação informativa e os limites para restringi-lo: análise do Volkszählungsurteil; 3. O direito à autodeterminação informativa como critério de constitucionalidade do uso de DNA para fins de persecução penal; 4. Considerações finais; 5. Referências.

\section{INTRODUÇÃO}

O processo penal tornou-se instrumento de combate à criminalidade, com a incumbência de garantir a segurança pública. Surge, junto ao direito penal simbólico, um processo penal simbólico que é utilizado como sedante da opinião pública. Na tentativa de obter soluções simples, rápidas e eficientes para o problema da criminalidade, o direito apoia-se em planos milagrosos e no terror da legislação simbólica. Com isso, tem se percebido um fenômeno denominado de expansão do Direito Penal, por meio do qual são aprovadas medidas drásticas em detrimento de garantias individuais, porque estas obstaculizariam a eficiência do sistema penal. ${ }^{1}$ Nesse contexto, a prova de DNA é apresentada à sociedade como o Santo Graal das provas científicas, a ferramenta perfeita na luta contra a criminalidade, e, sob esses argumentos, o interesse público se sobrepõe facilmente ao privado em uma análise de proporcionalidade.

1 JAKOBS, Günther. MELIÁ, Manuel Cancio. Direito penal do inimigo: noções e críticas. 6. ed. Tradução de André Luís Callegari e Nereu José Giacomolli. Porto Alegre: Livraria do Advogado, 2015. 
Quando se fala em genética forense, existe um "efeito CSI" que, ao mesmo tempo em que reforça o apoio público ao uso de DNA para fins de persecução penal, também reforça a crença de que o perfil genético seria uma tecnologia simples, barata, rápida, eficaz, infalível e inofensiva. Mas como nem tudo que reluz é ouro, a crítica especializada desconstrói esses argumentos e demonstra que, embora a prova de DNA possa ser mais precisa que outras práticas forenses, ela não representa uma solução em si para o problema da criminalidade, além de ser falível e, muitas vezes, subjetiva. Além disso, o perfil genético, embora frequentemente comparado com uma impressão digital, não é tão inofensivo e pode sim revelar informações pessoais sensíveis.

A análise jurídica da genética forense é desafiadora, tendo em vista que é uma ciência complexa e que é revolucionada constantemente: a todo momento são desenvolvidas técnicas inovadoras de análise do DNA e do próprio perfil genético que se transformam em novas possibilidades para a persecução penal. Além disso, argumentos tendenciosos e até desprovidos de comprovação científica são amplamente difundidos, atingindo diversas esferas institucionais, inclusive o Poder Judiciário, e prejudicando a discussão e o desenvolvimento da cultura jurídica brasileira sobre o tema. Nesse contexto, um juízo adequado de constitucionalidade e proporcionalidade depende, cada vez mais, de que juristas se apropriem de conhecimentos técnicos. Por isso, pesquisas interdisciplinares já desenvolvidas anteriormente pelas autoras são tomadas aqui como um pressuposto teórico desse artigo, assim como a experiência da Clínica de Direitos Humanos da Universidade Federal do Paraná (CDH|UFPR), que atua desde 2011 nessa temática, seja no controle preventivo de constitucionalidade, com pesquisa desenvolvida para a Secretaria de Assuntos Legislativos do Ministério da Justiça, seja na atuação como Amicus Curiae no RE no 973.837/MG, ou, ainda, na nota técnica enviada ao Projeto de Lei do Pacote Anticrime. ${ }^{2}$

\footnotetext{
2 SCHIOCCHET, Taysa; CUNHA, Anita Spies da. Desmistificando o DNA: análise dos argumentos difundidos na arena jurídica que levaram à aprovação dos bancos de perfis genéticos no Brasil. [S. I.], 2020.

CUNHA, Anita Spies; SCHIOCCHET, Taysa. Bancos de perfis genéticos para fins de persecução criminal: implicações jurídicas à privacidade, intimidade e estigmatização genéticas. In: SCHIOCCHET, Taysa; GARRIDO, Rodrigo Grazinoli (org.). Bancos de perfis genéticos para fins de persecução criminal: práticas periciais e impactos jurídico-sociais. Rio de Janeiro: Multifoco, 2018. p. 127-154.

SCHIOCCHET, Taysa (coord.). Banco de perfis genéticos para fins de persecução criminal. Braślia: Ministério da Justiça, 2012. (Série Pensando o Direito, 43). Disponível em: http://pensando.mj.gov.br/wp-content/ uploads/2015/07/Volume-4311.pdf. Acesso em: 20 maio 2020.

CLÍNICA DE DIREITOS HUMANOS UFPR. Memoriais. ev. 134 - Petição de apresentação de manifestação (14320/2018). Curitiba, 16 mar. 2018. In: BRASIL. Supremo Tribunal Federal. Recurso Extraordinário no 973.837/MG. Tema 905 - Constitucionalidade da inclusão e manutenção de perfil genético de condenados por crimes violentos ou por crimes hediondos em banco de dados estatal. Recorrente: Wilson Carmindo da Silva. Recorrido: Ministério Público do Estado de Minas Gerais. Relator: Ministro Gilmar Mendes. Em tramitação. Disponível em: http://redir.stf.jus.br/paginadorpub/paginador.jsp?docTP=TP\&doclD=726317153\&pr$\mathrm{ClD}=4991018 \#$. Acesso em: 27 maio 2020.

SCHIOCCHET, Taysa. RICHTER, Vitor. LOUZADA, Luiza. Nota técnica sobre as alterações na regulação dos bancos de perfis genéticos para fins de investigação criminal previstas no "pacote anticrime": Ref.
} 
No Brasil, a implementação e regulação do uso de DNA para fins de persecução penal teve como pano de fundo legitimador esse argumento de combate à criminalidade, influenciado pelo "efeito CSI", que, inserido em uma ainda incipiente cultura de proteção de dados, como é a brasileira, levou à aprovação da Lei 12.654/12, que, com apenas quatro artigos, passou a permitir a coleta, manutenção e utilização de dados genéticos para fins de persecução penal, sem regular adequadamente seu funcionamento, sendo omissa em vários aspectos. Como consequência, exatamente 4 anos depois de sua promulgação, a Lei teve sua constitucionalidade questionada, e atualmente o Recurso Extraordinário (RE) n॰ 973.837/MG está concluso para julgamento, com a repercussão geral reconhecida (Tema 905 - Constitucionalidade da inclusão e manutenção de perfil genético de condenados por crimes violentos ou por crimes hediondos em banco de dados estatal). Entretanto, a discussão sobre o assunto tem se concentrado, quase que exclusivamente, na esfera do direito penal e processual penal (especialmente no direito de não autoincriminação), existindo pouca interlocução com o direito civil-constitucional.

A visão monocular da questão, apenas sob o prisma penal, afastou da análise outros direitos fundamentais não diretamente relacionados ao direito penal, como os direitos de personalidade ligados à proteção de dados pessoais. A superação da cisão entre direito público e privado e entre os ramos do direito, e a consequente ampliação da análise das implicações jurídicas do uso de DNA para fins de persecução penal, é essencial para a regulação constitucional da matéria, em observância à tutela integral da dignidade humana, sem descuidar das especificidades de cada ramo do direito.

Na era da informação, com o avanço desenfreado de tecnologias de processamento de dados, por meio das quais órgãos públicos e privados podem impor uma vigilância massiva da população, a constitucionalidade do uso de DNA para fins de persecução penal depende, cada vez mais, do respeito aos direitos de personalidade. Em outras medidas processuais-penais, como a interceptação telefônica ou a quebra do sigilo de comunicações eletrônicas (mensagens de WhatsApp, por exemplo), o potencial de violação a direitos de personalidade, como a intimidade e a privacidade, é pacificamente reconhecido, e até a Constituição Federal estabelece, como direito fundamental, o sigilo das comunicações (art. 50, XII). O mesmo rigoroso filtro constitucional, atento aos direitos de personalidade, deve recair sobre a utilização de DNA para fins de persecução penal, uma vez que essa tecnologia pode violar esses direitos.

Diferentemente do Brasil, a implementação dos bancos de perfis genéticos em outros países veio acompanhada de discussão e de normativas relacionadas à proteção da privacidade e dos dados genéticos, tendo a Corte Europeia de Direitos Humanos

projeto de lei n 882/2019. Curitiba: Clínica de Direitos Humanos UFPR: 29 maio 2019. Disponível em: https:// www.linkedin.com/feed/update/urn:li:activity:6579532656906641408/. Acesso em: 24 maio 2020 
(ECHR) reconhecido, inclusive, que o armazenamento indiscriminado de perfis genéticos viola o direito de privacidade dos indivíduos. ${ }^{3}$ Já a Alemanha parte do direito geral de personalidade para estabelecer o direito à autodeterminação informativa como parâmetro de constitucionalidade para o armazenamento de perfis genéticos nos bancos.

Diante disso, este artigo tem como objetivo identificar e analisar os critérios de proporcionalidade utilizados pelo Tribunal Constitucional Alemão frente ao uso de perfis genéticos para fins de persecução criminal e ao direito à autodeterminação informativa e, por consequência, suas possíveis implicações à análise de constitucionalidade do tema no Brasil, pendente de julgamento pelo STF.

Elegemos, como contraponto ao Direito brasileiro, o Direito alemão, e, mais precisamente, a construção jurisprudencial do Tribunal Constitucional quanto às limitações e restrições de direitos fundamentais, ao considerar, por um lado, a esfera do indivíduo (direito à autodeterminação informativa), e por outro, o interesse público (segurança pública e persecução penal) na análise do uso de perfis genéticos. A escolha pela interlocução com o Direito alemão se justifica por ser, assim como o Brasil, um sistema jurídico de civil law; por ter critérios de inclusão e retenção de perfis genéticos similares; pela repercussão mundial da jurisprudência alemã sobre autodeterminação informativa; e pela forte influência que as teorias alemãs (especialmente em direitos fundamentais) têm no Direito brasileiro. Entendemos que eventuais divergências ou contrastes oriundos da análise comparada podem servir como complementação e referência adicional à análise da jurisprudência brasileira sobre o caso, ainda em formação.

No que tange à metodologia utilizada, a pesquisa é qualitativa, de cunho exploratório e em relação ao método de abordagem, o dialético, em razão da dinamicidade do fenômeno social estudado, além do estudo de caso comparado entre o Brasil e Alemanha. As técnicas de pesquisa utilizadas foram: pesquisa bibliográfica e documental.

Assim, tendo em vista o objetivo do presente artigo, a autoras apresentam uma interlocução entre o uso de DNA na persecução penal com o direito civil-constitucional e da proteção de dados, apoiando-se no posicionamento do Tribunal Constitucional Alemão quanto ao direito à autodeterminação informativa e, especialmente, na necessidade de uma análise individualizada de proporcionalidade para que a obtenção do

\footnotetext{
3 "In conclusion, the Court finds that the blanket and indiscriminate nature of the powers of retention of the fingerprints, cellular samples and DNA profiles of persons suspected but not convicted of offences, as applied in the case of the present applicants, fails to strike a fair balance between the competing public and private interests and that the respondent State has overstepped any acceptable margin of appreciation in this regard. Accordingly, the retention at issue constitutes a disproportionate interference with the applicants' right to respect for private life and cannot be regarded as necessary in a democratic society. This conclusion obviates the need for the Court to consider the applicants' criticism regarding the adequacy of certain particular safeguards, such as too broad an access to the personal data concerned and insufficient protection against the misuse or abuse of such data.".

CORTE EUROPEIA DE DIREITOS HUMANOS (ECHR). Case of S. and Marper v. The United Kingdom: Judgment. Strasburgo, 04 dez. 2008. p. 35. Disponível em: https://rm.coe.int/168067d216. Acesso em: 27 maio 2020.
} 
perfil genético seja constitucional. Para tanto, na primeira parte deste artigo, as autoras apresentam os principais elementos do direito à autodeterminação informativa e, como um direito não absoluto, os limites para sua restrição, a partir da análise do Caso do Censo (Volkszählungsurteil) de 1983 do Tribunal Constitucional Alemão. Na segunda parte, tomando como parâmetro o caso Genetischer Fingerabdruck I, de 2000, do Tribunal Constitucional Alemão, as autoras apresentam o direito à autodeterminação informativa como limite ao uso de DNA para fins de persecução penal, tanto na Alemanha como no Brasil.

\section{O DIREITO À AUTODETERMINAÇÃO INFORMATIVA E OS LIMITES PARA RESTRINGI-LO: ANÁLISE DO VOLKSZÄHLUNGSURTEIL}

Também chamado de autodeterminação informacional (em alemão, Recht auf informationelle Selbstimmung), esse direito "dá ao indivíduo o poder, de ele próprio decidir acerca da divulgação e utilização de seus dados pessoais". ${ }^{4}$ Segundo Wüsteney, ${ }^{5}$ na Alemanha, a autodeterminação informativa já havia sido citada em casos especíicos antes, mas apenas consolidou-se como Direito Fundamental na decisão do Tribunal Constitucional Alemão sobre o "Caso do Censo", ${ }^{6}$ ou Volkszählungsurteil" (BVerfGE $65,1)$. A partir de então, o direito à autodeterminação informativa passou a aplicar-se

4 MENKE, Fabiano. A proteção de dados e o direito fundamental à garantia da confidencialidade e da integridade dos sistemas técnico-informacionais no direito alemão. Revista Jurídica Luso-Brasilera, Lisboa, ano 5, n. 1, p. 788, 2019. Disponível em: http://www.cidp.pt/revistas/rjlb/2019/1/2019_01_0781_0809.pdf. Acesso em: 29 abr. 2020.

5 WÜSTENEY, Matthias. Rechtliche Zulässligkeit sogennanter DNA-Massentests zur Ermittlung des Täters einer Straftat. Frankfurt: Peter Lang, 2003. p. 137.

6 Em apertada síntese, a Lei do Censo (Volkszählungsgesetz) de 1983, ordenou o recenseamento geral da população, com dados sobre a profissão, moradia e local de trabalho para fins estatísticos. Além de prever a obrigatoriedade da participação, a lei também previa a possibilidade de uma comparação dos dados levantados com os registros públicos e também a transmissão de dados tornados anônimos a repartições públicas federais, estaduais e municipais. Ao final, decidiu o Tribunal que aquela pesquisa não implicava em registro e classificação de dados pessoais incompatível com a dignidade humana, porque satisfazia os requisitos de legalidade e proporcionalidade, mas declarou a inconstitucionalidade dos dispositivos que permitiam a comparação e trocas de dados. O caso tornou-se um marco mundial para o reconhecimento do direito à autodeterminação informacional.

MARTINS, Leonardo (org.). Cinqüenta Anos de Jurisprudência do Tribunal Constitucional Federal Alemão. Berlin: Konrad-Adenauer-Stiftung, 2005. Disponível em: http://www.kas.de/wf/doc/kas_7738-544-1-30.pdf. Acesso em: 27 maio 2020.

DEUTSCHLAND. Bundesverfassungsgericht. BVerfGE 65, 1 - Volkszählung. 1 BvR 209/83, 1 BvR 484/83, 1 BvR 440/83, 1 BvR 420/83, 1 BvR 362/83, 1 BvR 269/83. Alemanha, 15 de dezembro de 1983. Disponível em: http:// www.servat.unibe.ch/dfr/bv065001.html. Acesso em: 27 maio 2020.

7 Diante da relevância do julgado para este trabalho, optou-se por realizar uma análise aprofundada de seu texto original, em alemão. Tal decisão baseia-se nas precauções que devem ser tomadas na pesquisa comparativa, apresentadas por Marc Ancel, entre elas o cuidado com as traduções de termos jurídicos. Os trechos citados foram traduzidos livremente pelas autoras, quando isso se fez necessário, para manter a fluidez do texto, com o cuidado de colacionar em nota a versão no idioma original, visando manter a integridade da pesquisa. ANCEL, Marc. Utilidades e Métodos do Direito Comparado. Porto Alegre: Fabris, 1980. p. 111. 
automaticamente a todos os tipos de processamento de informações pelo Estado, inclusive sobre as informações genéticas humanas para fins de persecução penal. Hoje, tanto a União Europeia como diversos países (inclusive o Brasil) reconhecem o direito originado como construção jurisprudencial do Tribunal Constitucional Alemão. ${ }^{8}$

Na decisão, o Tribunal apresenta o direito à autodeterminação como derivado da dignidade humana e do direito geral de personalidade, como se vê no seguinte trecho:

[...] no centro da ordem constitucional estão o valor e a dignidade da pessoa, que, por meio da livre autodeterminação, atua como membro de uma sociedade livre. A proteção à dignidade humana também serve ao direito geral de personalidade [...], que se torna ainda mais significante diante da evolução moderna e os perigos que ela traz à personalidade humana. [...] As concretizações feitas até hoje pela jurisprudência descrevem o conteúdo do direito geral de personalidade, mas não de forma exaustiva. [...] Ele integra também o direito decorrente dessa ideia de autodeterminação, de o indivíduo poder decidir, quando e dentro de quais limites os seus dados pessoais são divulgados. ${ }^{9}$ (grifo nosso).

Epping ${ }^{10}$ explica que, para o livre desenvolvimento da personalidade, a pessoa necessita não só ter controle sobre os seus dados, como também o poder de decidir sobre a revelação de suas informações pessoais. Assim, a própria dignidade humana e o direito de personalidade pressupõem autodeterminação informativa, que encontra naquelas seu amparo legal.

Segundo o Tribunal, esse direito necessita de proteção especial diante das tecnologias de processamento automático de dados, uma vez que os dados pessoais podem ser armazenados ilimitadamente, acessados a qualquer momento virtualmente e, com a integração dos sistemas, as informações podem ser cruzadas a fim de montar uma "imagem da personalidade" (Persönlichkeitsbild), sobre a qual o indivíduo afetado

8 DONEDA, Danilo. A proteção dos dados pessoais como um direito fundamental. Espaço Jurídico, Joaçaba v. 12, n. 2, p. 95, jul./dez., 2011.

9 "Im Mittelpunkt der grundgesetzlichen Ordnung stehen Wert und Würde der Person, die in freier Selbstbestimmung als Glied einer freien Gesellschaft wirkt. Ihrem Schutz dient - neben speziellen Freiheitsverbürgungen - das [...] gewährleistete allgemeine Persönlichkeitsrecht, das gerade auch im Blick auf moderne Entwicklungen und die mit ihnen verbundenen neuen Gefährdungen der menschlichen Persönlichkeit Bedeutung gewinnen kann [...]. Die bisherigen Konkretisierungen durch die Rechtsprechung umschreiben den Inhalt des Persönlichkeitsrechts nicht abschließend. Es umfasst [...] auch die aus dem Gedanken der Selbstbestimmung folgende Befugnis des Einzelnen, grundsätzlich selbst zu entscheiden, wann und innerhalb welcher Grenzen persönliche Lebenssachverhalte offenbart werden [...]... DEUTSCHLAND. Bundesverfassungsgericht.

BVerfGE 65, 1 - Volkszählung. Alemanha, 15 de dezembro de 1983. p. 2. Disponível em: http://www.servat. unibe.ch/dfr/bv065001.html. Acesso em: 27 maio 2020.

10 EPPING, Volker. Grundrechte. 5. ed. Alemanha: Springer, 2012. p. 284. Disponível em: https://link.springer. com/book/10.1007\%2F978-3-642-28376-5. Acesso em: 27 maio 2020. 
não tem qualquer controle. Sobre isso, explica Mendes ${ }^{11}$ que "[o]s dados pessoais são projeções diretas da personalidade e como tal devem ser considerados.", razão pela qual todo tratamento de dados influencia na representação da pessoa na sociedade e, consequentemente, pode violar seus direitos fundamentais.

Por essas razões, o indivíduo deve ter a liberdade não só de decidir sobre a divulgação de seus dados, mas também de conduzir sua vida de acordo com essas decisões. Em outras palavras, a pessoa necessita ter pleno domínio do que é sabido sobre ela e como essas informações são utilizadas, para que possa avaliar suas consequências.

Quem teme que desvios de comportamento possam ser registrados o tempo todo e que essas informações são armazenadas, utilizadas ou divulgadas a terceiros, vai tentar evitar demonstrar este comportamento. Por exemplo, quem assumir que a participação em uma manifestação ou iniciativa civil será registrada pelo governo e que isso pode Ihe trazer riscos, pode não exercer seu direito fundamental de livre manifestação e associação. Isso não somente restringe as possibilidades de desenvolvimento pessoal do indivíduo, como também prejudica o bem comum, pois a autodeterminação é um requisito elementar para o funcionamento de uma sociedade democrática livre fundada na liberdade de agir e participar dos seus membros. ${ }^{12}$ (grifo nosso).

Para Epping, ${ }^{13}$ trata-se de um efeito de intimidação que afeta a percepção de liberdade do indivíduo ("nachhaltiger Einschüchterungseffekt auf die Freiheitswahrnehmung"). É por conta disso que o direito à autodeterminação informativa decorre do direito geral de personalidade, que, por sua vez, é um desdobramento da dignidade humana. Ora, o indivíduo intimidado, que não sabe quais informações o Estado detém sobre si, irá evitar certas atitudes, o que implicará diretamente no livre desenvolvimento e a livre expressão de sua personalidade, parte essencial da dignidade humana.

Assim, conclui o Tribunal que o direito fundamental ao livre desenvolvimento da personalidade protege o indivíduo contra o armazenamento, coleta, utilização e compartilhamento ilimitados de seus dados pessoais, com o mesmo fundamento legal, qual seja, Art. 2, Abs. 1 cominado com o Art. 1, Abs. 1 da Lei Fundamental. “O Direito

\footnotetext{
11 MENDES, Laura Schertel. A Lei Geral de Proteção de Dados Pessoais: um modelo de aplicação em três níveis. Caderno Especial LGPD. São Paulo: Ed. RT, 2019. p. 45.

12 "Wer damit rechnet, dass etwa die Teilnahme an einer Versammlung oder einer Bürgerinitiative behördlich registriert wird und dass ihm dadurch Risiken entstehen können, wird möglicherweise auf eine Ausübung seiner entsprechenden Grundrechte (Art 8,9 GG) verzichten. Dies würde nicht nur die individuellen Entfaltungschancen des Einzelnen beeinträchtigen, sondern auch das Gemeinwohl, weil Selbstbestimmung eine elementare Funktionsbedingung eines auf Handlungsfähigkeit und Mitwirkungsfähigkeit seiner Bürger begründeten freiheitlichen demokratischen Gemeinwesens ist.."

DEUTSCHLAND. Bundesverfassungsgericht. BVerfGE 65, 1 - Volkszählung. Alemanha, 15 de dezembro de 1983. p. 31. Disponível em: http://www.servat.unibe.ch/dfr/bv065001.html. Acesso em: 27 maio 2020.

13 EPPING, Volker. Grundrechte. 5. ed. Alemanha: Springer, 2012. p. 284. Disponível em: https://link.springer. com/book/10.1007\%2F978-3-642-28376-5. Acesso em: 27 maio 2020.
} 
Fundamental garante, nesse sentido, o direito do indivíduo de, basicamente, decidir sobre a divulgação e utilização de seus dados pessoais". ${ }^{4}$

O Tribunal, contudo, não apresenta o direito como absoluto. A decisão do Censo explicita que o indivíduo não tem um direito de domínio absoluto e ilimitado sobre seus dados, uma vez que o desenvolvimento do indivíduo e da sua personalidade ocorre em sociedade, cuja base é a comunicação. Além disso, quando há uma tensão entre os direitos individuais e o bem comum, a lei fundamental alemã tende a decidir em favor do dever e atuação cívica dos indivíduos. "Por isso, devem os indivíduos aceitar limitações no seu direito à autodeterminação informativa quando predomina o interesse público". ${ }^{15}$

De um modo geral, e notadamente na esfera penal e da persecução criminal por parte do Estado, essa possibilidade de limitação ${ }^{16}$ dos direitos fundamentais requer "instrumentos destinados a controlar as ingerências exercidas sobre os direitos fundamentais, evitando ao máximo a sua fragilização... ${ }^{17}$ A doutrina e a jurisprudência constitucional alemãs são as principais responsáveis pelo desenvolvimento desses instrumentos, tidos como "limites dos limites" dos direitos fundamentais. É precisamente nesse contexto do direito constitucional e dos direitos fundamentais que situamos a importância da interlocução entre o direito público e privado e, mais especificamente, da autodeterminação informativa, como corolário da proteção de dados pessoais sensíveis, na esfera penal.

Segundo o Tribunal Constitucional Alemão, para que sejam válidas, essas limitações devem: (1) ter fundamento legal e (2) observar atentamente o princípio da proporcionalidade, sem violar o núcleo essencial do direito. Esse princípio decorre da própria natureza dos Direitos Fundamentais, que somente podem ser limitados na medida

14 "Das Grundrecht gewährleistet insoweit die Befugnis des Einzelnen, grundsätzlich selbst über die Preisgabe und Verwendung seiner persönlichen Daten zu bestimmen."

DEUTSCHLAND. Bundesverfassungsgericht. BVerfGE 65, 1 - Volkszählung. 1 BvR 209/83, 1 BvR 484/83, 1 BvR 440/83, 1 BvR 420/83, 1 BvR 362/83, 1 BvR 269/83. Alemanha, 15 de dezembro de 1983. p. 31. Disponível em: http://www.servat.unibe.ch/dfr/bv065001.html. Acesso em: 27 maio 2020.

15 DEUTSCHLAND. Bundesverfassungsgericht. BVerfGE 65, 1 - Volkszählung. 1 BvR 209/83, 1 BvR 484/83, 1 BvR 440/83, 1 BvR 420/83, 1 BvR 362/83, 1 BvR 269/83. Alemanha, 15 de dezembro de 1983. p. 32. Disponível em: http://www.servat.unibe.ch/dfr/bv065001.html. Acesso em: 27 maio 2020.

16 A compreensão acerca do âmbito de proteção e dos limites dos direitos fundamentais depende se for adotada a teoria interna ou a teoria externa. Para a teoria interna, os limites são imanentes e "o direito tem o seu alcance definido de antemão, de tal sorte que sua restrição se revela desnecessária e até mesmo impossível do ponto de vista lógico". Nessa teoria, não há separação entre o âmbito de proteção e os limites do direito fundamental, não havendo conflito de direitos. Já na teoria externa, o direito é prima facie ilimitado, e apenas no caso concreto, diante da necessidade de compatibilizar diferentes bens jurídicos, é que o direito se apresenta limitado. Há colisão de direitos fundamentais, que deverão ser limitados para assegurar a convivência harmônica dos titulares dos direitos.

SARLET, Ingo Wolfgang. Curso de direito constitucional. 8. ed. São Paulo: Saraiva, 2018. p. 391-392.

17 SARLET, Ingo Wolfgang. Curso de direito constitucional. 8. ed. São Paulo: Saraiva, 2018. p. 397. 
indispensável à proteção do interesse público. ${ }^{18}$ As restrições aos direitos fundamentais que não respeitarem os limites dos limites serão, consequentemente, inconstitucionais.

No Brasil, a Constituição Federal não tem previsão expressa acerca dos limites dos limites, que decorrem de construção doutrinária e jurisprudencial. ${ }^{19}$ Diferentemente, no sistema jurídico alemão, há previsão constitucional expressa dos critérios para restrição de direitos fundamentais, no art. 19, II da Lei Fundamental:20

Artigo 19 [Restrição dos direitos fundamentais - Via judicial]

(1) Na medida em que, segundo esta Lei Fundamental, um direito fundamental possa ser restringido por lei ou em virtude de lei, essa lei tem de ser genérica e não limitada a um caso particular. Além disso, a lei terá de citar o direito fundamental em questão, indicando o artigo correspondente.

(2) Em nenhum caso, um direito fundamental poderá ser violado em sua essência. [...]

O direito à autodeterminação informativa, assim como os demais direitos fundamentais, não tem um cerne previamente definido, razão pela qual a violação ao núcleo essencial também deverá ser analisada considerando as características e peculiaridades do direito em conflito e do caso concreto. Ademais, para verificação do núcleo deste direito, não basta considerar o dado em si, mas também o seu tratamento e os possíveis usos. De todo modo, considera-se abstratamente que há uma violação ao núcleo essencial do direito à autodeterminação informativa quando se retira completamente do sujeito o seu espaço privado necessário para desenvolver sua personalidade livremente. ${ }^{21}$

Desse modo, quanto à análise de proporcionalidade relativa ao direito à autodeterminação informativa, para o Tribunal Constitucional Alemão, não só o tipo de informação é relevante, como também as suas possibilidades de utilização e a utilidade desta informação. Deve ser considerado qual o objetivo do Estado com a informação coletada e quais possibilidades de utilização e combinação dessa informação serão possíveis de acordo com a tecnologia utilizada.

\footnotetext{
18 DEUTSCHLAND. Bundesverfassungsgericht. BVerfGE 65, 1 - Volkszählung. 1 BvR 209/83, 1 BvR 484/83, 1 BvR 440/83, 1 BvR 420/83, 1 BvR 362/83, 1 BvR 269/83. Alemanha, 15 de dezembro de 1983. p. 32. Disponível em: http://www.servat.unibe.ch/dfr/bv065001.html. Acesso em: 27 maio 2020.

19 Exemplificando, o STF trata expressamente da teoria dos limites dos limites (fl. 742 e seguintes) no voto proferido pelo Ministro Relator Gilmar Mendes no Recurso Extraordinário n 511.961/SP, que tratava da (in) constitucionalidade da exigência de diploma para exercício da profissão de jornalista.

20 ALEMANHA. Lei Fundamental da República Federal da Alemanha. Berlin: Deutscher Bundestag, 2011. Disponível em: https://www.btg-bestellservice.de/pdf/80208000.pdf. Acesso em: 27 maio 2020.

21 DEUTSCHLAND. Bundesverfassungsgericht. BVerfGE 34, 238 - Tonband. 2 BvR 454/71. Alemanha, 31. Januar 1973. Disponível em: https://www.servat.unibe.ch/dfr/bv034238.html. Acesso em: 27 maio 2020.
} 
Assim, Wüsteney ${ }^{22}$ refere que, na análise de proporcionalidade envolvendo o direito de autodeterminação informativa, quando se trata de processamento de informações, não existe informação pessoal sem importância. ${ }^{23}$ É claro que a informação pessoal pode estar em uma esfera mais ou menos íntima do indivíduo. Entretanto, aqui não se trata da informação em si, mas sim da sua coleta, armazenamento, utilização e compartilhamento. Nesse sentido, pode-se dizer que toda informação poderá atingir o direito à autodeterminação informativa, pois até mesmo informações que parecem inofensivas podem ser prejudiciais a depender da sua utilização. Nesse sentido decidiu o Tribunal Constitucional:

Com isso, pode um dado visto em si como sem importância ganhar um novo status; com o processamento automático de dados não existe, nesse contexto, nenhum dado "sem importância". O quanto uma informação é sensível aqui não depende apenas se ela atinge a intimidade. Para estabelecer a importância de um dado para o direito da personalidade é muito mais necessário conhecer o contexto da sua utilização (grifo nosso). ${ }^{24}$

O Tribunal esclarece que, para poder limitar o direito à autodeterminação informativa, deve-se considerar todas as possibilidades de utilização e combinação das informações na análise da proporcionalidade, e não o grau de "intimidade" da informação em si. Para Limbeck ${ }^{25}$ mesmo que não exista um dado sem importância, há um núcleo da personalidade que é intocável pelo poder público. Por isso, ainda que o direito à autodeterminação informativa possa ser limitado quando o interesse público superar o privado, as restrições devem obedecer ao critério da proporcionalidade. De qualquer forma, qualquer utilização de dados pessoais pelo Estado deverá ser justificada e acompanhada de regras para a proteção do indivíduo. ${ }^{26}$

22 WÜSTENEY, Matthias. Rechtliche Zulässligkeit sogennanter DNA-Massentests zur Ermittlung des Täters einer Straftat. Frankfurt: Peter Lang, 2003. p. 138.

23 Para Mendes, após a promulgação da LGPD, também há esse entendimento no Brasil: "A Lei Geral de Proteção de Dados (LGPD) inaugura um modelo ex ante de proteção de dados, fundado na ideia de que não existem mais dados irrelevantes em face do processamento automatizado e ubíquo de dados na sociedade da informação".

MENDES, Laura Schertel. A Lei Geral de Proteção de Dados Pessoais: um modelo de aplicação em três níveis. Caderno Especial LGPD. São Paulo: Ed. RT, 2019. p. 44-45

24 DEUTSCHLAND. Bundesverfassungsgericht. BVerfGE 65, 1 - Volkszählung. 1 BvR 209/83, 1 BvR 484/83, 1 BvR 440/83, 1 BvR 420/83, 1 BvR 362/83, 1 BvR 269/83. Alemanha, 15 de dezembro de 1983. p. 32. Disponível em: http://www.servat.unibe.ch/dfr/bv065001.html. Acesso em: 27 maio 2020.

25 LIMBECK, Jutta. Die erkennungsdienstliche Behandlung und die DNA-Identitätsfeststellung gem. 81g StPO. Hamburg: Verlag Dr. Kovac, 2007. p. 120.

26 WÜSTENEY, Matthias. Rechtliche Zulässligkeit sogennanter DNA-Massentests zur Ermittlung des Täters einer Straftat. Frankfurt: Peter Lang, 2003. p. 145. 


\section{O DIREITO À AUTODETERMINAÇÃO INFORMATIVA COMO CRI- TÉRIO DE CONSTITUCIONALIDADE DO USO DE DNA PARA FINS DE PERSECUÇÃO PENAL}

Não seria diferente com a utilização de DNA para fins de persecução penal. Enquanto que, no Brasil, ela ainda foi pouco confrontada com o direito de autodeterminação informativa - uma vez que o estudo desse direito quase se limita às esferas de direito da internet - na Alemanha, por outro lado, o direito à autodeterminação informativa é apresentado como limite à coleta e utilização do DNA na persecução penal.

Wüsteney ${ }^{27}$ refere que na Alemanha o direito à autodeterminação informativa ocupa posição de grande importância no debate da análise de DNA. As primeiras publicações sobre o tema, ainda anteriores à lei de identificação pelo DNA (DNA-ldentitätsfeststellungsgesetz), de 1999, já mencionavam a autodeterminação informativa. Entretanto, mesmo naquele país houve certa resistência à aplicação do direito à autodeterminação informativa na persecução penal, uma vez que, enquanto muitos reconhecem a indispensabilidade da proteção de dados também e sobretudo na persecução penal, outros entendem que uma proteção de dados tão ampla é incompatível com o objetivo do processo penal, que é localizar o culpado o mais rápido possível. De fato, a proteção dos dados pessoais não é absoluta, mas de certa forma limitará a persecução penal. Trata-se, assim, de encontrar a equilíbrio caso a caso, com o sopesamento dos valores envolvidos, especialmente os interesses públicos e privados.

Atualmente, na Alemanha, o entendimento sobre a temática está consolidado no sentido de que toda e qualquer utilização de informação genética pelo Estado atingirá o direito fundamental à autodeterminação informativa, configurando-se uma restrição ao seu exercício e à sua proteção. Isso não impede a utilização de DNA para fins de persecução penal, eis que não se trata de direito absoluto, mas impõe que sejam respeitados os limites dos limites, ou seja, deve haver (1) fundamentação legal e (2) observância estrita à proporcionalidade no caso concreto, preservando-se o núcleo essencial do direito. ${ }^{28}$

Os parâmetros para essa verificação de constitucionalidade decorrem de posicionamento jurisprudencial do Tribunal Constitucional Alemão, no precedente conhecido como Genetischer Fingerabdruck I. ${ }^{29}$ Esse foi o primeiro julgado alemão a analisar

27 WÜSTENEY, Matthias. Rechtliche Zulässligkeit sogennanter DNA-Massentests zur Ermittlung des Täters einer Straftat. Frankfurt: Peter Lang, 2003. p. 145-146.

28 Sob esse aspecto é que seriam analisadas violações específicas a direitos nas diferentes fases da cadeia de custódia (coleta, processamento, armazenamento e uso probatório no processo penal). Sobre essas fases e suas repercussões jurídicas, ver:

CABEZUDO BAJO, Maria José. La prueba de ADN: valoración preliminar de la regulación Española y la Union Europea. In: MONIZ, Helena; MACHADO, Helena (orgs). Bases de dados genéticos forenses: tecnologias de controlo e ordem social. Coimbra: Coimbra Editora, 2014. p. 103-140.

29 DEUTSCHLAND. Bundesverfassungsgericht. BVerfGE 103, 21 - Genetischer Fingerabdruck I. 2 BvR 1741/99, 2 BvR 276/00, 2 BvR 2061/00. Alemanha, 14 de dezembro de 2000. Disponível em: http://www.bverfg. de/e/rk20001214_2bvr174199.html. Acesso em: 27 maio 2020. 
o armazenamento de perfis genéticos para fins de persecução penal à luz do direito à autodeterminação informativa e acabou gerando uma modificação no Código de Processo Penal alemão, que incorporou os critérios fixados na decisão. ${ }^{30}$ As reclamações constitucionais (2 BvR 1741/99, 2 BvR 276/00 e 2 BvR 2061/00) questionavam ordens judiciais que determinaram a coleta de células e a realização de testes genéticos para a obtenção do perfil genético para permitir a identificação em casos criminais futuros e foi recebida porque instâncias inferiores não consideraram o direito fundamental à autodeterminação informativa. ${ }^{31}$

O Tribunal decidiu que, enquanto o uso de DNA para fins de persecução penal se limitar à coleta do perfil genético, acessando apenas a parte não-codificante ${ }^{32}$ do DNA e com o descarte imediato da amostra genética, não haverá violação ao núcleo essencial do direito. ${ }^{33}$ Entretanto, "a obtenção, o armazenamento e a (futura) utilização do perfil genético atinge, de fato, o direito fundamental à autodeterminação informativa garantido nos Art. 2, alínea c/c Art. 1, alínea 1, GG" e“Essa garantia somente pode ser limitada por lei ou por causa de uma lei, quando o interesse público se sobrepor, e sob a observância do princípio constitucional da proporcionalidade".34 Tal proporcionalidade

30 §81g do Código de Processo Penal Alemão (tradução nossa, grifo nosso): (1) ${ }^{1}$ Se o acusado é suspeito de um crime de grande importância ou de um crime contra a autodeterminação sexual, é permitido coletar células dele e examiná-las para obter o perfil genético e o sexo, para fins de identificação em crimes futuros, quando a natureza do crime ou o modo como foi cometido, a personalidade do agente, ou outra informação, permita assumir que outras investigações de crimes de importância considerável serão conduzidas contra ele no futuro. ${ }^{2} \mathrm{O}$ cometimento repetido de outros crimes pode ser considerado um ilícito equivalente a um crime de importância considerável. [...]

31 DEUTSCHLAND. Bundesverfassungsgericht. BVerfGE 103, 21 - Genetischer Fingerabdruck I. 2 BvR 1741/99, 2 BvR 276/00, 2 BvR 2061/00. Alemanha, 14 de dezembro de 2000. p. 42-43. Disponível em: http:// www.bverfg.de/e/rk20001214_2bvr174199.html. Acesso em: 27 maio 2020.

32 A divisão entre região codificante e não-codificante do DNA está diretamente relacionada aos perfis genéticos, pois um dos principais argumentos da "inofensividade" do perfil genético é que ele é retirado da parte não-codificante do DNA, que não produz proteínas e, por isso, não teria função no organismo. Assim, a análise dessa parte do DNA não poderia revelar informações pessoais. Entretanto, atualmente já foram identificadas diversas funções para as áreas não-codificantes do DNA, razão pela qual essa divisão hoje já não basta para impedir a revelação de informações pessoais, tanto é que ela não é adotada pela legislação alemã.

33 Dies gilt jedenfalls, solange sich die Eingriffsermächtigung nur auf den nicht-codierenden, zu etwa 30\% aus Wiederholungseinheiten bestehenden Anteil der DNA bezieht [...], ausschließlich die Feststellung des DNA-Identifizierungsmusters zum Zweck der Identitätsfeststellung BVerfGE in künftigen Strafverfahren vorgenommen und das Genmaterial nach der Feststellung des DNA-Identifizierungsmusters vernichtet wird...

DEUTSCHLAND. Bundesverfassungsgericht. BVerfGE 103, 21 - Genetischer Fingerabdruck I. 2 BvR 1741/99, 2 BvR 276/00, 2 BvR 2061/00. Alemanha, 14 de dezembro de 2000. p. 9. Disponível em: http://www.bverfg. de/e/rk20001214_2bvr174199.html. Acesso em: 27 maio 2020.

34 Die Feststellung, Speicherung und (künftige) Verwendung des DNA-Identifizierungsmusters greifen allerdings in das durch Art. 2 Abs. 1 GG i.V.m. Art. 1 Abs. 1 GG verbürgte Grundrecht auf informationelle Selbstbestimmung ein. [...] Diese Verbürgung darf nur im überwiegenden Interesse der Allgemeinheit und unter Beachtung des Grundsatzes der Verhältnismäßigkeit durch Gesetz oder aufgrund eines Gesetzes eingeschränkt werden...

DEUTSCHLAND. Bundesverfassungsgericht. BVerfGE 103, 21 - Genetischer Fingerabdruck I. 2 BvR 1741/99, 2 BvR 276/00, 2 BvR 2061/00. Alemanha, 14 de dezembro de 2000. p. 49. Disponível em: http://www.bverfg. de/e/rk20001214_2bvr174199.html. Acesso em: 27 maio 2020. 
deve ser aferida no caso concreto, mediante uma análise individualizada, não sendo suficiente a simples repetição do texto da lei, frisando que "as referências genéricas a estatísticas de criminalidade ou a dados criminológicos não fundamentados também não substituem a análise caso a caso que é exigida".35

Para a legitimidade da coleta compulsória do perfil genético, a decisão judicial deverá apresentar um prognóstico negativo (Negativprognose) baseado no risco de repetição dos crimes, fundado em fatos documentados, coerentes e processualmente valoráveis, e não simplesmente uma probabilidade de reincidência (Prognoseentscheidung). Esse prognóstico negativo deverá indicar que o indivíduo poderá cometer crimes de importância considerável, e que o armazenamento do perfil genético poderá auxiliar nestas futuras investigações. ${ }^{36} 37$

Desse modo, fica evidente que a motivação individualizada no caso concreto para determinar ou não a inclusão do condenado no banco de perfis genéticos, prevista no ordenamento alemão, é muito diferente de uma decisão judicial meramente fundamentada no enquadramento legal. No Brasil, há previsão constitucional de que "todos os julgamentos dos órgãos do Poder Judiciário serão públicos, e fundamentadas todas as decisões, sob pena de nulidade" (art. 93, IX). Apesar disso, a coleta compulsória do perfil genético está sendo aplicada como efeito automático da sentença penal, sem nem mesmo necessitar de mandamento judicial específico, de forma que poderia ser aplicada, inclusive, retroativamente àqueles que foram condenados antes da entrada em vigor da lei.

Adotando-se os parâmetros propostos pela decisão alemã, a inserção quase automática do perfil genético do condenado no banco, motivada apenas pelo enquadramento do fato como crime hediondo ou "praticado, dolosamente, com violência de natureza grave contra pessoa", com fulcro no art. 90-A da Lei n 7.210/84 (Lei de Execuções Penais), não seria adequadamente fundamentada, pois essa restrição ao direito fundamental depende, necessariamente, da demonstração da proporcionalidade no caso concreto. Tal dispositivo está sendo questionado no Supremo Tribunal Federal, no

\footnotetext{
35 "Auch allgemeine Hinweise auf die,Kriminalstatistik' oder nicht weiter belegte kriminologische Erkenntnisse ersetzen die gebotene Einzelfallprüfung nicht..".

DEUTSCHLAND. Bundesverfassungsgericht. BVerfGE 103, 21 - Genetischer Fingerabdruck I. 2 BvR 1741/99, 2 BvR 276/00, 2 BvR 2061/00. Alemanha, 14 de dezembro de 2000. p. 57 e 65. Disponível em: http://www.bverfg.de/e/rk20001214_2bvr174199.html. Acesso em: 27 maio 2020.

36 Assim, não seria possível o armazenamento do perfil genético quando os crimes que o indivíduo poderá cometer sejam pouco relevantes, ou quando o perfil genético não puder auxiliar naquele tipo de investigação. Por exemplo, se a probabilidade é de que o indivíduo cometa crimes cibernéticos, não se justificaria o armazenamento do perfil genético, eis que a comparação entre perfis genéticos não auxilia uma investigação de crimes realizados pela internet.
}

37 DEUTSCHLAND. Bundesverfassungsgericht. BVerfGE 103, 21 - Genetischer Fingerabdruck I. 2 BvR 1741/99, 2 BvR 276/00, 2 BvR 2061/00. Alemanha, 14 de dezembro de 2000. p. 72. Disponível em: http://www. bverfg.de/e/rk20001214_2bvr174199.html. Acesso em: 27 maio 2020. 
Recurso Extraordinário no $973.837 .{ }^{38}$ Contudo, até o momento, a discussão jurisprudencial não teve como foco principal o direito à autodeterminação informativa, mas sim a não autoincriminação. Muito embora o Ministro Relator, na decisão de afetação do tema à repercussão geral, tenha reconhecido uma possível violação a direitos da personalidade, ampliando as possibilidades do debate que está por vir na corte superior.

De fato, a cultura jurídica brasileira de proteção de dados ainda é incipiente e, nesse contexto, praticamente só a doutrina especializada reconhece o direito à autodeterminação informativa como direito fundamental no Brasil. Assim, por um lado, é compreensível que esse direito não ocupe posição central na discussão nacional acerca da constitucionalidade da coleta compulsória de perfis genéticos. Por outro lado, como demonstramos ao longo desse texto, o direito à autodeterminação informativa pode fazer parte da solução jurídica a ser moldada pelo Supremo Tribunal Federal para a questão. Nesse sentido, da mesma forma como na Alemanha o reconhecimento do direito se deu por construção jurisprudencial, os juristas brasileiros já podem amparar suas decisões no direito à autodeterminação informativa, amparando-se no parágrafo $2^{\circ}$ do artigo $5^{\circ}$ da Constituição Federal de $1988 .^{39}$

Além do amparo constitucional, agora, com a Lei Geral de Proteção de Dados (LGPD), a legislação infraconstitucional brasileira reconhece expressamente a autodeterminação informativa como fundamento da proteção de dados pessoais. ${ }^{40}$ Apesar de a lei trazer previsão expressa que excepciona sua aplicação ao tratamento de dados pessoais realizado para fins de "atividades de investigação e repressão de infrações penais (art. 4 , III, "d"), "[t]ais exceções, no entanto, são moldadas de forma a não comprometer a integridade da lei, visto que para diversas delas refere-se à existência de legislação específica sobre proteção de dados que compreenda os princípios da LGPD".41 É o que diz o art. $4^{\circ}, \S 1^{\circ}$ da LGPD:

$\S 1^{\circ} \mathrm{O}$ tratamento de dados pessoais previsto no inciso III será regido por legislação específica, que deverá prever medidas proporcionais e estritamente necessárias ao

\footnotetext{
38 Para uma análise pormenorizada dessa e de outras previsões e omissões da Lei $n^{\circ} 12.654 / 12$, ver: SCHIOCCHET, Taysa. Reflexões jurídicas acerca da regulamentação dos bancos de perfis genéticos para fins de investigação criminal no Brasil. In: MONIZ, Helena; MACHADO, Helena (orgs). Bases de dados genéticos forenses: tecnologias de controlo e ordem social. Coimbra: Coimbra Editora, 2014. p. 67-102.

39 " $§ 2^{\circ}$ Os direitos e garantias expressos nesta Constituição não excluem outros decorrentes do regime e dos princípios por ela adotados, ou dos tratados internacionais em que a República Federativa do Brasil seja parte." BRASIL. [Constituição (1988)]. Constituição da República Federativa do Brasil de 1988. Brasília, DF: Presidência da República, 1988. Disponível em: http://www.planalto.gov.br/ccivil_03/constituicao/constituicao.htm. Acesso em: 27 maio 2020.

40 Sobre o contexto internacional e nacional de produção da LGPD e uma proposta a sua aplicação em três níveis (condições de legitimidade, garantias reais de proteção e sanções e reparação), ver: MENDES, Laura Schertel. A Lei Geral de Proteção de Dados Pessoais: um modelo de aplicação em três níveis. Caderno Especial LGPD. São Paulo: Ed. RT, 2019. p. 35-56.

41 MENDES, Laura Schertel. A Lei Geral de Proteção de Dados Pessoais: um modelo de aplicação em três níveis. Caderno Especial LGPD. São Paulo: Ed. RT, 2019. p. 46.
} 
atendimento do interesse público, observados o devido processo legal, os princípios gerais de proteção e os direitos do titular previstos nesta Lei (grifo nosso). ${ }^{42}$

Conforme Louzada, ${ }^{43}$ pelo diálogo de fontes, os princípios da LGPD ${ }^{44}$ se aplicam à regulação dos bancos de perfis genéticos, devendo orientar sua elaboração e interpretação em benefício do titular dos dados. Mais que isso, os princípios de proteção de dados da LGPD são essenciais para o exercício da autodeterminação informativa por parte dos titulares de dados genéticos, eis que poderão "garantir a instrumentalização de outros direitos que transcendem a proteção de dados e a privacidade, como o acesso à justiça, a igualdade, o contraditório e a ampla defesa".45

A legislação brasileira já caminha na direção da proteção do direito à autodeterminação informativa também no âmbito da utilização de DNA para fins de persecução penal. Nesse sentido, destaca-se positivamente a alteração legislativa ${ }^{46}$ recente (Lei nº 13.964, de 2019), que trouxe as seguintes inovações:

§10-A. A regulamentação deverá fazer constar garantias mínimas de proteção de dados genéticos, observando as melhores práticas da genética forense.

$\S 3^{\circ}$ Deve ser viabilizado ao titular de dados genéticos o acesso aos seus dados constantes nos bancos de perfis genéticos, bem como a todos os documentos da cadeia de custódia que gerou esse dado, de maneira que possa ser contraditado pela defesa. ${ }^{47}$

A autodeterminação informativa não apenas impõe uma limitação à atuação do Estado, como também cria um espaço de atuação positiva para o titular dos dados

42 BRASIL. Lei no 13.709, de 14 de agosto de 2018. Lei Geral de Proteção de Dados Pessoais (LGPD). Brasília, DF: Presidência da República, 2018. Disponível em: http://www.planalto.gov.br/ccivil_03/_ato20152018/2018/lei/L13709.htm. Acesso em: 27 maio 2020.

43 LOUZADA, Luiza. Princípios da LGPD e os bancos de perfis genéticos: instrumentalizados a garantia de direitos no processo penal. Revista do Advogado, São Paulo, v. 39, n. 144, p. 10, nov. 2019.

44 Sobre os princípios da LGPD e suas diversas repercussões, inclusive em termos de Privacy by Design, ver: MENDES, Laura Schertel; BIONI, Bruno R. O Regulamento Europeu de Proteção de Dados Pessoais e a Lei Geral de Proteção de Dados Brasileira: mapeando convergências na direção de um nível de equivalência. Revista de Direito do Consumidor, v. 124, ano 28, p. 157-180, São Paulo, jul.-ago. 2019.

45 LOUZADA, Luiza. Princípios da LGPD e os bancos de perfis genéticos: instrumentalizados a garantia de direitos no processo penal. Revista do Advogado, São Paulo, v. 39, n. 144, p. 14, nov. 2019.

46 Quanto ao projeto de lei que antecedeu a referida legislação, indicamos a leitura da Nota Técnica da CDH|UFPR encaminhada ao Grupo de Trabalho da Câmara de Deputados (2019), coordenado pela deputada Margarete Coelho, destinado a analisar as mudanças promovidas na legislação penal e processual penal pelos projetos de lei $n^{\circ} 10.372 / 18,10.373 / 18$ e 882/19.

SCHIOCCHET, Taysa. RICHTER, Vitor. LOUZADA, Luiza. Nota técnica sobre as alterações na regulação dos bancos de perfis genéticos para fins de investigação criminal previstas no "pacote anticrime": Ref. projeto de lei no 882/2019. Curitiba: Clínica de Direitos Humanos UFPR: 29 maio 2019. Disponível em: https://www. linkedin.com/feed/update/urn:li:activity:6579532656906641408/. Acesso em: 24 maio 2020.

47 BRASIL. Lei $\mathbf{n}^{\circ}$ 13.964, de 24 de dezembro de 2019. Aperfeiçoa a legislação penal e processual penal. Brasília, DF: Presidência da República, 2019. Disponível em: http://www.planalto.gov.br/ccivil_03/_ato20192022/2019/lei/L13964.htm. Acesso em: 27 maio 2020. 
genéticos. Conforme Doneda, ${ }^{48}$ ao compreender o tratamento de dados pessoais como um processo que vai além da autorização da pessoa para utilização de seus dados, a autodeterminação informativa busca incluir a pessoa nas demais fases do processo de tratamento dos seus dados. Não basta, portanto, o simples reconhecimento, por parte da legislação, do direito à autodeterminação, uma vez que apenas uma minoria enfrentaria o Estado para exercer essa prerrogativa. ${ }^{49}$

$\mathrm{O}$ direito à autodeterminação informativa existe ainda que ausente o consentimento, e principalmente nesses casos ele ganha especial relevância: a coleta compulsória de dados restringe o direito, mas não pode anulá-lo por completo. Diante disso, é necessário que a legislação específica, amparando-se nos princípios e direitos previstos na LGPD, crie mecanismos e ferramentas para que os titulares possam exercer este direito. Na perspectiva dos bancos de perfis genéticos, considerando a compulsoriedade da coleta e a impossibilidade de o indivíduo impedir o uso de seus dados, cabe à legislação estabelecer salvaguardas de forma a proteger o titular de tratamento inadequado ou ilícito de dados, sob pena de afetação desproporcional e inconstitucional aos direitos fundamentais.

Para Cabezudo Bajo, ${ }^{50}$ a regulação do uso de DNA para fins de persecução penal deve obedecer a dois requisitos:

1) en primer lugar, si dicha regulación posibilita la obtención de una prueba de ADN lo más fiablemente posible; 2) en segundo término, si permite la obtención de una prueba de ADN lícitamente; ello, a su vez, significa que ha de obtenerse, de un lado, con el máximo respeto a los derechos fundamentales que puedan verse afectados $y$, de otro, en cumplimiento de los correspondientes requisitos legalmente previstos. (grifo nosso).

Enquanto a fiabilidade da prova está relacionada com a estrita observância da cadeia de custódia - que foi incluída expressamente no Código de Processo Penal, arts. 158-A a 158-F, pela Lei 13.964/2019 (Pacote Anticrime) -, a licitude depende tanto do cumprimento dos requisitos legais para obtenção da prova como também e principalmente do respeito aos direitos fundamentais. ${ }^{51}$ Ambos os elementos (fiabilidade e lici-

48 DONEDA, Danilo. A proteção dos dados pessoais como um direito fundamental. Espaço Jurídico, Joaçaba v. 12, n. 2, p. 97-98, jul./dez., 2011.

49 DONEDA, Danilo. A proteção dos dados pessoais como um direito fundamental. Espaço Jurídico, Joaçaba v. 12, n. 2, p. 98, jul./dez., 2011.

50 CABEZUDO BAJO, Maria José. La prueba de ADN: valoración preliminar de la regulación Española y la Union Europea. In: MONIZ, Helena; MACHADO, Helena (orgs). Bases de dados genéticos forenses: tecnologias de controlo e ordem social. Coimbra: Coimbra Editora, 2014. p. 104.

51 Doutrinariamente, a prova ilegal divide-se em ilegítima, que é a que viola regras de processo penal no momento de sua produção; e ilícita, que é a que viola regra de direito material ou a própria Constituição: "Em geral, ocorre uma violação da intimidade, privacidade ou dignidade". LOPES JÚNIOR, Aury. Direito processual penal. 17. ed. São Paulo: Saraiva Educação, 2020. 
tude) devem estar presentes em cada uma das fases do uso forense de DNA: obtenção da amostra biológica; análise da amostra e obtenção do perfil genético em laboratório; inserção e tratamento do perfil genético no banco. "Si ambos requisitos de cumplen en las tres fases, podremos afirmar que la regulación permite la obtención de una prueba de descargo o, en su caso, de cargo que puede fundamentar, junto con otros medios de prueba, una sentencia de condena...52

Nesse sentido, a inconstitucionalidade da coleta e do armazenamento do perfil genético no banco não representará apenas uma violação ao direito daquele indivíduo, mas também implicará necessariamente na ilicitude de todas as provas que decorram desse perfil genético armazenado no banco. Consequentemente, a própria finalidade do banco, que é auxiliar investigações e a persecução penal, estará prejudicada, pois nenhuma prova que, em sua essência, viole desproporcionalmente direitos fundamentais poderá fundamentar uma condenação penal. Assim, reiteramos, além de estabelecer mecanismos que garantam a observância da cadeia de custódia (fiabilidade), a regulação dos bancos de perfis genéticos deve estabelecer critérios de inclusão e restrições no tratamento desses dados que sejam proporcionais aos direitos fundamentais atingidos, especialmente a autodeterminação informativa.

Essa análise de proporcionalidade deve considerar, além dos elementos do caso concreto, como propõe o julgado alemão analisado, também outros elementos relacionados à própria tecnologia dos bancos de perfis genéticos. Assim, o jurista precisa buscar conhecimentos interdisciplinares que Ihe permitam conhecer a técnica, seus verdadeiros riscos e benefícios e, para isso, será necessário colocar luz sobre argumentos difundidos como senso comum. ${ }^{53}$ Nesse sentido, a análise de proporcionalidade deverá considerar, por exemplo, que não existem evidências concretas acerca da contribuição dos bancos de perfis genéticos para a segurança pública; ${ }^{54}$ que, apesar de mais precisa que muitas outras técnicas forenses, ainda é falível e, muitas vezes, depende da subjetividade do perito; ${ }^{55}$ que a prova de DNA não é inofensiva e não pode ser comparada

52 CABEZUDO BAJO, Maria José. La prueba de ADN: valoración preliminar de la regulación Española y la Union Europea. In: MONIZ, Helena; MACHADO, Helena (orgs). Bases de dados genéticos forenses: tecnologias de controlo e ordem social. Coimbra: Coimbra Editora, 2014. p. 105.

53 As autoras escreveram outro texto visando suprir essa lacuna de uma análise crítica e interdisciplinar dos argumentos técnicos e extralegais sobre uso forense do DNA: SCHIOCCHET, Taysa; CUNHA, Anita Spies da. Desmistificando o DNA: análise dos argumentos difundidos na arena jurídica que levaram à aprovação dos bancos de perfis genéticos no Brasil. [S. I.], 2020.

54 Amankwaa e McCartney desenvolveram um abrangente estudo dos diferentes indicadores e métodos de avaliação da efetividade dos bancos de DNA para fins de persecução penal. Ao final, concluíram que "Yet what evidence exists shows that while DNA databases may offer slightly improved detection or conviction rates, the overall contribution of DNA databases to public security may be negligible".

AMANKWAA Aaron Opoku; MCCARTNEY Carole. The effectiveness of the UK national DNA database. Forensic Science International: Synergy, v. 1, p. 45-55, 2019. DOI: 10.1016/j.fsisyn.2019.03.004.

55 Nesse sentido, ver THOMPSON, William C. The Myth of Infallibility. In: KRIMSKY, Sheldon, GRUBER, Jeremy. Genetic Explanations: Sense and Nonsense. Cambridge: Harvard University Press, 2013. p. 227-256. e 
com uma impressão digital, eis que pode revelar informações pessoais sensíveis, como informações familiares ${ }^{56}$ ou características físicas. ${ }^{57}$

Quanto a isso, destaca-se que o Pacote Anticrime previa a inclusão de um parágrafo na Lei de Execuções Penais que vedava a realização de testes fenotípicos e buscas familiares, mas o dispositivo foi vetado pela Presidência da República. ${ }^{58} \mathrm{~A}$ Presidência da República também vetou o dispositivo legal que determinava a imediata destruição das amostras, embora a manutenção das amostras biológicas deixe exposta toda a carga genética do indivíduo e, assim, deixe uma infinidade de informações pessoais sensíveis vulneráveis a abusos no tratamento dos dados. ${ }^{59}$

\section{CONSIDERAÇÕES FINAIS}

O respeito à autodeterminação informativa é requisito para o exercício da cidadania e seu reconhecimento, que no Brasil era apenas doutrinário, atualmente já está positivado com a LGPD. Assim, para a legitimidade do uso de DNA para fins de persecução penal, especialmente do banco de perfis genéticos, é necessária uma compatibilização com o direito fundamental à autodeterminação informativa. Reconhecer a incidência deste direito no âmbito da persecução penal não impede a utilização do DNA,

MURPHY, Erin. The Art in the Science of DNA: A Layperson's Guide to the Subjectivity Inherent in Forensic DNA Typing. Emory Law Journal, v. 58, n. 489, p. 101-124, 2008. Disponível em: https://ssrn.com/abstract=1753906. Acesso em: 27 maio 2020.

56 CUNHA, Anita Spies; SCHIOCCHET, Taysa. Bancos de perfis genéticos para fins de persecução criminal: implicações jurídicas à privacidade, intimidade e estigmatização genéticas. In: SCHIOCCHET, Taysa; GARRIDO, Rodrigo Grazinoli (org.). Bancos de perfis genéticos para fins de persecução criminal: práticas periciais e impactos jurídico-sociais. Rio de Janeiro: Multifoco, 2018. p. 127-154.

57 Nesse sentido, destacamos que a proibição legal de "revelar traços somáticos ou comportamentais das pessoas", constante no art. 5-A da Lei no 12.037/09 (Identificação Criminal) refere-se, apenas, às "informações genéticas contidas nos bancos de dados de perfis genéticos" (BRASIL, 2009). Assim, seria possível a realização de testes fenotípicos (FDP - forensic DNA phenotyping), desde que o resultado dos testes não seja armazenado no banco, o que não impede que seja utilizado em investigações ou como prova processual. Sobre FDP, ver: SAMUEL, G.; PRAINSACK, B. Societal, ethical, and regulatory dimensions of forensic DNA phenotyping. Visage: set. 2019. Disponível em: http://www.visage-h2020.eu/PDF/Delliverable_5.2_for_online_publication_ vo1.pdf.

58 BRASIL. Presidência da República. Mensagem n 726, de 24 de dezembro de 2019. Disponível em: http:// www.planalto.gov.br/ccivil_03/_ato2019-2022/2019/Msg/VEP/VEP-726.htm. Acesso em: 27 maio 2020.

59 A justificativa do veto foi que a manutenção da amostra seria necessária para eventual reteste. Ocorre que o parágrafo vetado fazia referência à amostra genética dos indivíduos condenados e, sendo necessário um reteste, bastaria coletar novo material do indivíduo. Entendemos que a manutenção da amostra biológica para reteste se justifica exclusivamente para as amostras coletadas nas cenas de crime (vestígios).

Sobre as implicações jurídicas da retenção de amostras biológicas, ver: SCHIOCCHET, Taysa; CUNHA, CUNHA, Anita Spies; SCHIOCCHET, Taysa. Bancos de perfis genéticos para fins de persecução criminal: implicações jurídicas à privacidade, intimidade e estigmatização genéticas. In: SCHIOCCHET, Taysa; GARRIDO, Rodrigo Grazinoli (org.). Bancos de perfis genéticos para fins de persecução criminal: práticas periciais e impactos jurídico-sociais. Rio de Janeiro: Multifoco, 2018. p. 127-154. 
eis que ele não é absoluto, mas impõe uma análise de proporcionalidade, bem como medidas assecuratórias para proteger o direito fundamental em questão e assegurar a constitucionalidade da medida.

Tal análise deve, inicialmente, verificar a integridade do núcleo essencial do direito à autodeterminação informativa. Seguindo o parâmetro do Tribunal Constitucional Alemão, anteriormente indicado, o núcleo essencial estará resguardado se a medida se restringir à coleta do perfil genético, sem revelar traços fenotípicos e com o descarte imediato da amostra genética. Ocorre que a legislação brasileira deixa margem para a realização de testes genéticos fenotípicos (FDP) durante uma investigação criminal, por exemplo, e silencia quanto ao descarte das amostras biológicas. Diante de tal fragilidade legislativa, a adoção do posicionamento do Tribunal Constitucional Alemão no Brasil implicaria na inconstitucionalidade da legislação brasileira, por proteção deficiente ao direito fundamental à autodeterminação informativa. Nessa linha de raciocínio, caberia ao Supremo Tribunal Federal modular a interpretação da legislação de modo a proteger o núcleo essencial do Direito, vedando as práticas que sejam incompatíveis.

Uma vez resguardado o cerne intangível do direito fundamental, restaria analisar se a medida que restringe o direito fundamental é proporcional. Nesse sentido, a medida restritiva deve ser necessária, razoável e estritamente proporcional, sem excessos e sem deficiências. Nesse ponto também devem ser consideradas as salvaguardas e garantias existentes para que não ocorra uma violação não autorizada ao direito fundamental. É nesse momento de análise da proporcionalidade concreta da medida que o jurista precisa ter um cuidado maior para afastar-se das falácias do excepcionalismo e do minimalismo genéticos.

Por um lado, o jurista levará em consideração o interesse público que justifica a o uso de DNA para fins de persecução penal: a segurança pública e a efetividade da persecução penal. A tecnologia dos perfis genéticos realmente pode contribuir positivamente, na medida em que o perfil genético permite confirmar a identidade de suspeitos já investigados e, quando inserido em um banco de dados automatizado, por meio da comparação de perfis genéticos, possibilita apontar novos suspeitos e relacionar vestígios entre si, mas ela não é infalível, estando sujeita a erros de interpretação e a problemas na cadeia de custódia. ${ }^{60}$

Por outro lado, uma análise de proporcionalidade adequada não poderá ignorar que o uso de DNA para fins de persecução penal expõe a identidade genética do indivíduo e, com isso, atinge os direitos de personalidade. Essa proporcionalidade será

60 CLÍNICA DE DIREITOS HUMANOS UFPR. Memoriais. ev. 134 - Petição de apresentação de manifestação (14320/2018). Curitiba, 16 mar. 2018. In: BRASIL. Supremo Tribunal Federal. Recurso Extraordinário nº 973.837/MG. Tema 905 - Constitucionalidade da inclusão e manutenção de perfil genético de condenados por crimes violentos ou por crimes hediondos em banco de dados estatal. Recorrente: Wilson Carmindo da Silva. Recorrido: Ministério Público do Estado de Minas Gerais. Relator: Ministro Gilmar Mendes. Em tramitação. Disponível em: http://redir.stf.jus.br/paginadorpub/paginador.jsp?docTP=TP\&docID=726317153\&pr$\mathrm{clD}=4991018 \#$. Acesso em: 27 maio 2020. 
diferente quando se trata de uma coleta perfil genético para fins de investigação (sem inserção no banco) e uma coleta de perfil genético para inclusão no banco. No âmbito da investigação (identificação criminal), há, por um lado, uma suspeita já existente sobre o indivíduo, e por outro, um interesse público na resolução de um caso concreto, já em andamento. Nesse caso, a necessidade da medida é mais palpável. Além disso, sem a inserção no banco de perfis genéticos, o indivíduo tem um maior controle e proteção sobre suas informações genéticas, o que diminui o grau de violação do direito à autodeterminação informativa.

Diferentemente, na inclusão do perfil genético no banco de dados, há apenas uma expectativa que isso poderá auxiliar na resolução de crimes futuros e poderá reduzir a criminalidade, porque sujeitos com o perfil genético no banco estariam menos sujeitos a cometer novos crimes (ainda que não exista comprovação científica disso). Nesse caso, há apenas uma expectativa de que aquele perfil genético será necessário no futuro. Mesmo em crimes hediondos, em muitos casos, nem mesmo há necessidade de consulta ao Banco de Perfis Genéticos, bastando a comparação do suspeito já identificado com o vestígio. ${ }^{61}$

Na Alemanha, o Tribunal Constitucional Federal determinou que a proporcionalidade da medida deveria ser analisada no caso concreto, com fundamentação expressa baseada no prognóstico negativo do indivíduo e na efetiva possibilidade de esse perfil genético auxiliar investigações futuras de crimes relevantes. Essa determinação foi, posteriormente, incluída no próprio texto legal. Diferentemente, a legislação brasileira não impõe a necessidade de análise de proporcionalidade no caso concreto, o que implica em uma restrição injustificada do direito fundamental à autodeterminação.

Veja-se que a redação da lei brasileira abre margem para a subjetividade do julgador, pois determina que serão submetidos obrigatoriamente à coleta os condenados por crime doloso (i) com violência de natureza grave contra a pessoa e (ii) por crimes hediondos (art. 90-A da Lei 7.210/84). ${ }^{62}$ Nesse contexto, tendo em vista que a lei não traz um conceito para "violência grave", caberá ao julgador atribuir sentido ao texto legal, sem haver critérios prévios para se basear. Contudo, a subjetividade brasileira se encerra na qualificação do crime já praticado pelo agente (é hediondo? houve violência grave?), ignorando o prognóstico negativo. A legislação infraconstitucional nem mesmo exige que o julgador determine expressamente a coleta de DNA de condenados em uma decisão devidamente fundamentada.

61 Em crimes sexuais, por exemplo, em 75,9\% dos casos o autor do crime era conhecido. FÓRUM BRASILEIRO DE SEGURANÇA PÚBLICA. BUENO, Samira; LIMA, Renato Sérgio de. (Coord.). Anuário brasileiro de segurança pública 2019. Ano 13, 2019. p. 118. Disponível em: http://www.forumseguranca.org.br/wp-content/uploads/2019/09/Anuario-2019-FINAL-v3.pdf. Acesso em: 27 maio 2020.

62 BRASIL. Lei nº 7.210, de 11 de julho de 1984. Institui a Lei de Execução Penal. Brasília, DF: Presidência da República, 1984. Disponível em: http://www.planalto.gov.br/ccivil_03/leis/L7210compilado.htm. Acesso em: 27 maio 2020. 
É importante que os mecanismos concretos de proteção do indivíduo contra abusos no tratamento de seus dados estejam previstos em lei ou, considerando que o tema está pendente de julgamento pelo Supremo Tribunal Federal, que sejam colocados como requisito de constitucionalidade pelo uso da técnica da interpretação conforme, rechaçando qualquer interpretação que desequilibre a relação entre interesses públicos e privados. Propõe-se, nesse sentido, a análise individualizada no caso concreto, nos termos da jurisprudência alemã acima discutida, que deverá ser mais rígida enquanto forem insuficientes as garantias de proteção de dados.

A necessidade de fundamentação expressa para a obtenção do perfil genético de condenados, ainda que não prevista em lei, decorre do mandamento constitucional de proteção dos direitos fundamentais e de motivação das decisões judiciais. Dessa forma, ao impor a coleta compulsória de DNA, a decisão judicial, para que seja adequadamente fundamentada, dependerá da ponderação das questões propostas nesse texto, e, especialmente, deverá considerar, no caso concreto, o prognóstico negativo do sujeito, ou seja, da efetiva probabilidade de reincidência em crimes graves, cujas investigações possam efetivamente ser auxiliadas pela comparação de perfis genéticos. A ausência dessa análise minuciosa implicará em uma restrição injustificada do direito à autodeterminação informativa e, consequentemente, na desproporcionalidade e inconstitucionalidade da medida e na ilicitude da prova.

\section{REFERÊNCIAS}

ALEMANHA. Lei Fundamental da República Federal da Alemanha. Berlin: Deutscher Bundestag, 2011. Disponível em: https://www.btg-bestellservice.de/pdf/80208000.pdf. Acesso em: 27 maio 2020.

AMANKWAA Aaron Opoku; MCCARTNEY Carole. The effectiveness of the UK national DNA database. Forensic Science International: Synergy, v. 1, p.45-55, 2019. DOI: 10.1016/j.fsisyn.2019.03.004.

ANCEL, Marc. Utilidades e Métodos do Direito Comparado. Porto Alegre: Fabris, 1980.

BRASIL. [Constituição (1988)]. Constituição da República Federativa do Brasil de 1988. Brasília, DF: Presidência da República, 1988. Disponível em: http://www.planalto.gov.br/ccivil_03/constituicao/constituicao.htm. Acesso em: 27 maio 2020.

BRASIL. Lei n 7.210, de 11 de julho de 1984. Institui a Lei de Execução Penal. Brasília, DF: Presidência da República, 1984. Disponível em: http://www.planalto.gov.br/ccivil_03/leis/L7210compilado.htm. Acesso em: 27 maio 2020.

BRASIL. Lei $\mathbf{n}^{\circ} \mathbf{1 2 . 0 3 7}$, de $\mathbf{1}^{\circ}$ de outubro de 2009. Dispõe sobre a identificação criminal do civilmente identificado, regulamentando o art. 5, inciso LVIII, da Constituição Federal. Brasília, DF: Presidência da República, 2009. Disponível em: http://www.planalto.gov.br/ccivil_03/_ato20072010/2009/lei/l12037.htm. Acesso em: 27 maio 2020. 
BRASIL. Lei no 12.654, de 28 de maio de 2012. Altera as Leis nos 12.037, de 10 de outubro de 2009, e 7.210, de 11 de julho de 1984 - Lei de Execução Penal, para prever a coleta de perfil genético como forma de identificação criminal, e dá outras providências. Brasília, DF: Presidência da República, 2012. Disponível em: http://www.planalto.gov.br/ccivil_03/_ato2011-2014/2012/lei/ I12654.htm. Acesso em: 27 maio 2020.

BRASIL. Lei n 13.709, de 14 de agosto de 2018. Lei Geral de Proteção de Dados Pessoais (LGPD). Brasília, DF: Presidência da República, 2018. Disponível em: http://www.planalto.gov.br/ccivil_03/_ato2015-2018/2018/lei/L13709.htm. Acesso em: 27 maio 2020.

BRASIL. Lei no 13.964, de 24 de dezembro de 2019. Aperfeiçoa a legislação penal e processual penal. Brasília, DF: Presidência da República, 2019. Disponível em: http://www.planalto.gov.br/ ccivil_03/_ato2019-2022/2019/lei/L13964.htm. Acesso em: 27 maio 2020.

BRASIL. Presidência da República. Mensagem n 726, de 24 de dezembro de 2019. Disponível em: http://www.planalto.gov.br/ccivil_03/_ato2019-2022/2019/Msg/VEP/VEP-726.htm. Acesso em: 29 abr. 2020.

BRASIL. Supremo Tribunal Federal. Recurso Extraordinário n 511.961/SP. Jornalismo. Exigência de diploma de curso superior, registrado pelo ministério da educação, para o exercício da profissão de jornalista. Liberdades de profissão, de expressão e de informação. Constituição de 1988

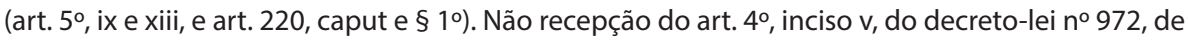
1969. [...]. Recorrente: Sindicato das empresas de rádio e televisão no estado de São Paulo. Recorrido: União. Relator: Ministro Gilmar Mendes, 17 de junho de 2009. Disponível em: http://redir.stf. jus.br/paginadorpub/paginador.jsp?docTP=AC\&docID=605643. Acesso em: 27 maio 2020.

BRASIL. Supremo Tribunal Federal. Recurso Extraordinário n 973.837/MG. Tema 905 - Constitucionalidade da inclusão e manutenção de perfil genético de condenados por crimes violentos ou por crimes hediondos em banco de dados estatal. Recorrente: Wilson Carmindo da Silva. Recorrido: Ministério Público do Estado de Minas Gerais. Relator: Ministro Gilmar Mendes. Em tramitação. Disponível em: http://portal.stf.jus.br/processos/detalhe.asp?incidente=4991018. Acesso em: 29 abr. 2020.

CABEZUDO BAJO, Maria José. La prueba de ADN: valoración preliminar de la regulación Española y la Union Europea. In: MONIZ, Helena; MACHADO, Helena (orgs). Bases de dados genéticos forenses: tecnologias de controlo e ordem social. Coimbra: Coimbra Editora, 2014. p. 103-140.

CLÍNICA DE DIREITOS HUMANOS UFPR. Memoriais. ev. 134 - Petição de apresentação de manifestação (14320/2018). Curitiba, 16 mar. 2018. In: BRASIL. Supremo Tribunal Federal. Recurso Extraordinário no 973.837/MG. Tema 905 - Constitucionalidade da inclusão e manutenção de perfil genético de condenados por crimes violentos ou por crimes hediondos em banco de dados estatal. Recorrente: Wilson Carmindo da Silva. Recorrido: Ministério Público do Estado de Minas Gerais. Relator: Ministro Gilmar Mendes. Em tramitação. Disponível em: http://redir.stf.jus.br/paginadorpub/paginador.jsp?docTP=TP\&docID=726317153\&prcID=4991018\#. Acesso em: 27 maio 2020. 
CORTE EUROPEIA DE DIREITOS HUMANOS (ECHR). Case of S. and Marper v. The United Kingdom: Judgment. Strasburgo, 04 dez. 2008. Disponível em: https://rm.coe.int/168067d216. Acesso em: 27 maio 2020.

CUNHA, Anita Spies; SCHIOCCHET, Taysa. Bancos de perfis genéticos para fins de persecução criminal: implicações jurídicas à privacidade, intimidade e estigmatização genéticas. In: SCHIOCCHET, Taysa; GARRIDO, Rodrigo Grazinoli (org.). Bancos de perfis genéticos para fins de persecução criminal: práticas periciais e impactos jurídico-sociais. Rio de Janeiro: Multifoco, 2018. p. 127-154.

DEUTSCHLAND. Bundesverfassungsgericht. BVerfGE 103, 21 - Genetischer Fingerabdruck I. 2 BvR 1741/99, 2 BvR 276/00, 2 BvR 2061/00. Alemanha, 14 de dezembro de 2000. Disponível em: http://www.bverfg.de/e/rk20001214_2bvr174199.html. Acesso em: 27 maio 2020.

DEUTSCHLAND. Bundesverfassungsgericht. BVerfGE 34, 238 - Tonband. 2 BvR 454/71. Alemanha, 31. Januar 1973. Disponível em: https://www.servat.unibe.ch/dfr/bv034238.html. Acesso em: 27 maio 2020.

DEUTSCHLAND. Bundesverfassungsgericht. BVerfGE 65, 1 - Volkszählung. 1 BvR 209/83, 1 BvR 484/83, 1 BvR 440/83, 1 BvR 420/83, 1 BvR 362/83, 1 BvR 269/83. Alemanha, 15 de dezembro de 1983. Disponível em: http://www.servat.unibe.ch/dfr/bv065001.html. Acesso em: 27 maio 2020.

DEUTSCHLAND. Strafprozeßordnung (StPO), de 12 de setembro de 1950. Strafprozeßordnung in der Fassung der Bekanntmachung vom 7. April 1987 (BGBI. I S. 1074, 1319), die zuletzt durch Artikel 3 des Gesetzes vom 22. April 2020 (BGBI. I S. 840) geändert worden ist. Disponível em: https:// www.gesetze-im-internet.de/stpo/BJNR006290950.html. Acesso em: 27 maio 2020.

DONEDA, Danilo. A proteção dos dados pessoais como um direito fundamental. Espaço Jurídico, Joaçaba v. 12, n. 2, p. 91-108, jul./dez., 2011.

EPPING, Volker. Grundrechte. 5. ed. Alemanha: Springer, 2012. Disponível em: https://link.springer.com/book/10.1007\%2F978-3-642-28376-5. Acesso em: 27 maio 2020.

FÓRUM BRASILEIRO DE SEGURANÇA PÚBLICA. BUENO, Samira; LIMA, Renato Sérgio de. (Coord.). Anuário brasileiro de segurança pública 2019. Ano 13, 2019. Disponível em: http://www.forumseguranca.org.br/wp-content/uploads/2019/09/Anuario-2019-FINAL-v3.pdf. Acesso em: 27 maio 2020.

FRÖNER; Henrique. As barreiras dos direitos fundamentais: estudo teórico e análise de decisão do Tribunal Constitucional Federal. Revista do Ministério Público do RS, Porto Alegre, n. 64, p. 85135, out-dez. 2009. Disponível em: https://www.amprs.com.br/public/arquivos/revista_artigo/ arquivo_1264074153.pdf. Acesso em: 27 maio 2020.

GLOECKNER, Ricardo Jacobsen. Nulidades no processo penal. 3. ed. São Paulo: Saraiva, 2017.

LIMBECK, Jutta. Die erkennungsdienstliche Behandlung und die DNA-Identitätsfeststellung gem. 81g StPO. Hamburg: Verlag Dr. Kovac, 2007.

LOPES JÚNIOR, Aury. Fundamentos do processo penal: introdução crítica. 2. ed. São Paulo: Saraiva, 2016. 
LOPES JÚNIOR, Aury. Direito processual penal. 17. ed. São Paulo: Saraiva Educação, 2020.

LOUZADA, Luiza. Princípios da LGPD e os bancos de perfis genéticos: instrumentalizados a garantia de direitos no processo penal. Revista do Advogado, São Paulo, v. 39, n. 144, p. 90-98, nov. 2019.

MACHADO, Helena et al. Bases de dados genéticos com fins forenses: Análise comparativa de legislação europeia. Coimbra, 2011. Relatório Técnico do projeto Base de dados de perfis de DNA com propósitos forenses em Portugal: questões atuais de âmbito ético, prático e político. Disponível em: https://www.researchgate.net/publication/276069555_Bases_de_dados_geneticos_ com_fins_forenses_Analise_comparativa_de_legislacao_europeia. Acesso em: 27 maio 2020.

MARTINS, Leonardo (org.). Cinqüenta Anos de Jurisprudência do Tribunal Constitucional Federal Alemão. Berlin: Konrad-Adenauer-Stiftung, 2005. Disponível em: http://www.kas.de/wf/ doc/kas_7738-544-1-30.pdf. Acesso em: 27 maio 2020.

MELIÁ, Manuel Cancio. Terrorism and criminal law: The dream of prevention, the nightmare of the rule of law. New Criminal Law Review, v. 14, n. 1, p. 108-122, 2011. DOI: 10.1525/nclr.2011.14.1.108.

MENDES, Laura Schertel. A Lei Geral de Proteção de Dados Pessoais: um modelo de aplicação em três níveis. Caderno Especial LGPD. São Paulo: Ed. RT, 2019. p. 35-56.

MENDES, Laura Schertel; BIONI, Bruno R. O Regulamento Europeu de Proteção de Dados Pessoais e a Lei Geral de Proteção de Dados Brasileira: mapeando convergências na direção de um nível de equivalência. Revista de Direito do Consumidor, v. 124, ano 28, p. 157-180, São Paulo, jul.-ago. 2019.

MENKE, Fabiano. A proteção de dados e o direito fundamental à garantia da confidencialidade e da integridade dos sistemas técnico-informacionais no direito alemão. Revista Jurídica Luso-Brasilera, Lisboa, ano 5, n. 1, p. 781-809, 2019. Disponível em: http://www.cidp.pt/revistas/ rjlb/2019/1/2019_01_0781_0809.pdf. Acesso em: 29 abr. 2020.

MURPHY, Erin. The Art in the Science of DNA: A Layperson's Guide to the Subjectivity Inherent in Forensic DNA Typing. Emory Law Journal, v. 58, n. 489, p. 101-124, 2008. Disponível em: https:// ssrn.com/abstract=1753906. Acesso em: 27 maio 2020.

NAVARRO, Ana Maria Neves de Paiva. O Direito Fundamental à Autodeterminação Informativa. In: CONPEDI/UFF (Org.). Direitos fundamentais e democracia II. XXI Congresso Nacional do CONPEDI. Florianópolis: FUNJAB, 2012. p. 410-438. Disponível em: http://www.publicadireito. com.br/publicacao/livro.php?gt=124. Acesso em: 27 maio 2020.

RUARO, Regina Linden. LIMBERGER, Têmis. Banco de dados de informações genéticas e administração pública como concretizadora da proteção dos dados pessoais e da dignidade humana. Novos Estudos Jurídicos, v. 18, n. 1, 2013. Disponível em: http://www6.univali.br/seer/index.php/ nej/article/viewFile/4486/2479. Acesso em: 27 maio 2020.

SARLET, Ingo Wolfgang. Curso de direito constitucional. 8. ed. São Paulo: Saraiva, 2018. 
SCHIOCCHET, Taysa (coord.). Banco de perfis genéticos para fins de persecução criminal. Brasília: Ministério da Justiça, 2012. (Série Pensando o Direito, 43). Disponível em: http://pensando. mj.gov.br/wp-content/uploads/2015/07/Volume-4311.pdf. Acesso em: 20 maio 2020.

SCHIOCCHET, Taysa. Reflexões jurídicas acerca da regulamentação dos bancos de perfis genéticos para fins de investigação criminal no Brasil. In: MONIZ, Helena; MACHADO, Helena (orgs). Bases de dados genéticos forenses: tecnologias de controlo e ordem social. Coimbra: Coimbra Editora, 2014. p. 67-102.

SCHIOCCHET, Taysa; CUNHA, Anita Spies da; LAZZARETTI, Bianca Kaini. Bancos de perfis genéticos para fins de persecução criminal: Implicações jurídicas à privacidade, intimidade e estigmatização genéticas. Anais da ReACT - Reunião de Antropologia da Ciência e Tecnologia, v. 2, n. 2, 2015. Disponível em: https://ocs.ige.unicamp.br/ojs/react/article/view/1355. Acesso em: 27 maio 2020.

SCHIOCCHET, Taysa. RICHTER, Vitor. LOUZADA, Luiza. Nota técnica sobre as alterações na regulação dos bancos de perfis genéticos para fins de investigação criminal previstas no "pacote anticrime": Ref. projeto de lei no 882/2019. Curitiba: Clínica de Direitos Humanos UFPR: 29 maio 2019. Disponível em: https://www.linkedin.com/feed/update/urn:liactivity:6579532656906641408/. Acesso em: 24 maio 2020.

TEPEDINO, Gustavo. A tutela da personalidade no ordenamento Civil-Constitucional Brasileiro. In: TEPEDINO, Gustavo. Temas de Direito Civil. 3. ed. rev. e atual. Rio de Janeiro: Renovar, 2004. p. 23-58.

THOMPSON, William C. The Myth of Infallibility. In: KRIMSKY, Sheldon, GRUBER, Jeremy. Genetic Explanations: Sense and Nonsense. Cambridge: Harvard University Press, 2013. p. 227-256.

WÜSTENEY, Matthias. Rechtliche Zulässligkeit sogennanter DNA-Massentests zur Ermittlung des Täters einer Straftat. Frankfurt: Peter Lang, 2003. 